\title{
INTERACTIVE DOCUMENTS: LANGUAGE FEATURES AND DOCUMENT STATUS
}

\author{
Elena S. Belous \\ Volgograd State Technical University, Volgograd, Russia
}

\begin{abstract}
The research is carried out in line with the current problems of modern document linguistics, related to the study of formation peculiarities, design and functioning of new types of documents. It is shown that currently there is a change in the structure of the document in two directions: the unification of the document form and the creation of documents without a clear structure. The concept of "interactive document" is introduced. It refers to a form of hypertext representation, a special material structure (code, program, existing in an electronic environment) created by a person to store and transmit information in space and time, adapted for reading the text (as a logical or associative sequence of speech or non-speech signs). The types of interactive documents (business portal, business website, paper work automation and electronic document management program) are identified. The specifics of the material carrier and the information component of the interactive document are characterized. It is shown that non-rigid structure is characteristic of interactive documents. It is established that information in interactive documents is transmitted through verbal and nonverbal components. The terminological richness of the verbal component of an interactive document and the tendency to move from official to less formal communication in an electronic environment, regardless of the business situation, are revealed. The classification of nonverbal features is developed. It is stated that they are more diverse in comparison with traditional hard copies.

Key words: Russian language, business communication, document, interactive document, hypertext, verbal component of the document text, non-verbal component of the document text.

Citation. Belous E.S. Interactive Documents: Language Features and Document Status. Vestnik Volgogradskogo gosudarstvennogo universiteta. Seriya 2. Yazykoznanie [Science Journal of Volgograd State University. Linguistics], 2021, vol. 20, no. 1, pp. 168-180. (in Russian). DOI: https://doi.org/10.15688/jvolsu2.2021.1.14
\end{abstract}

\section{ИНТЕРАКТИВНЫЕ ДОКУМЕНТЫ: ЯЗЫКОВЫЕ ОСОБЕННОСТИ И ДОКУМЕНТНЫЙ СТАТУС}

\section{Елена Сергеевна Белоус}

Волгоградский государственный технический университет, г. Волгоград, Россия

\begin{abstract}
Аннотация. Исследование выполнено в русле актуальных проблем современной документной лингвистики, связанных с изучением особенностей создания, оформления и функционирования новых видов документов. Показано, что в настоящее время происходит изменение структуры документа по двум направлениям: унификация формы документа и создание документов без четкой структуры. Введено понятие «интерактивный документ», под которым понимается форма представления гипертекста, специальная материальная конструкция (код, программа, бытующие в электронной среде), позволяющая хранить и передавать информацию в пространстве и времени, приспособленная для прочтения текста (как логической или ассоциативной последовательности речевых или неречевых знаков). Определены виды интерактивных документов (деловой портал, деловой сайт, программа автоматизации делопроизводства и электронного документооборота). Охарактеризована специфика материального носителя и информационной составляющей интерактивного документа. Установлено, что интерактивные документы отличаются нежесткой структурой; информац ция в интерактивных документах передается посредством вербального и невербального компонентов. Выяв-
\end{abstract}


лены терминологическая насыщенность вербального компонента интерактивного документа и тенденция перехода от официального к менее официальному общению в электронной среде, независимо от деловой ситуации. Разработана классификация элементов невербального компонента. Констатируется их большее разнообразие по сравнению с традиционными документами на бумажном носителе.

Ключевые слова: русский язык, деловое общение, документ, интерактивный документ, гипертекст, вербальный компонент документного текста, невербальный компонент документного текста.

Цитирование. Белоус Е. С. Интерактивные документы: языковые особенности и документный статус // Вестник Волгоградского государственного университета. Серия 2, Языкознание. - 2021. - Т. 20, № 1. C. 168-180.-DOI: https://doi.org/10.15688/jvolsu2.2021.1.14

\section{Введение}

Внимание исследователей к термину «документ» и понятию, обозначаемому данным термином, не ослабевает. Это связано не только с его широким употреблением в повседневной общественной жизни, но и с развитием терминологического аппарата давно существующих и новых научных дисциплин. Однако большинство работ посвящено описанию документов, принадлежащих к разным документным системам, но оформленным на традиционном (бумажном) носителе, хотя в настоящее время в сфере деловой коммуникации все чаще применяются интерактивные документы.

Повсеместная информатизация определила возникновение и развитие делового общения в электронной среде. Необходимость такого общения связана с услугами, предоставляемыми населению банками, государственными учреждениями, фирмами, разрабатывающими и распространяющими специальные программы для ведения бизнеса. Большое количество людей пользуется интернетмагазинами, системами бронирования и т. д. По мнению А.В. Литвинова и В.В. Матюшенко, это все является различными видами деловой коммуникации, которая осуществляется по установленным образцам и определенным правилам [Литвинов, Матюшенко, 2013, c. 107]. Ее субъектами выступают как юридические лица (государственные учреждения, органы законодательной, исполнительной и судебной власти, политические образования), так и физические лица (граждане, взаимодействующие с этими учреждениями, решающими различные вопросы в сфере образования, здравоохранения, производства и др.).

Эффективными инструментами современной деловой коммуникации, которая осу- ществляется с помощью виртуальных технических каналов, становятся интерактивные документы. Их изучение представляется актуальным и перспективным в целях оптимизации бизнес-процессов.

\section{Материал и методы}

Любой документ можно рассматривать с позиций документной лингвистики - научной дисциплины, изучающей технологии создания документа как коммуникативного инструмента управления [Кушнерук, Тюрикова, 2015]. Основным понятием для данной дисциплины является документный текст - функционально, содержательно, структурно и нормативно завершенное речевое единство, составляющее основной коммуникативный компонент документа, скрепленное модальностью, производной от функционально-нормативных условий документной коммуникации, и соответствующее унифицирующим или стандартизирующим правилам построения речи [Кушнерук, 2007, с. 49].

Именно документный текст интерактивного документа является объектом нашего исследования. Для его изучения использовались анализ, синтез, описание, сравнение. Определить особенности функционирования терминологии в интерактивных документах позволил метод логико-понятийного моделирования. Данный метод применим к разным предметным областям, в том числе связанным с деловой коммуникацией. Так, исследование терминологических единиц, характеризующих делопроизводство, позволило разработать классификацию терминов, в рамках которой выделяются их тематические группы и выстраивается иерархия понятий [Белоус, 2010].

Материалами исследования послужили документные тексты порталов «Госуслуги» 
(https://www.gosuslugi.ru), портала информационно-технического сопровождения $1 \mathrm{C}$ (https://portal.1c.ru), «КУЛЬТУРА.РФ» (https:// www.culture.ru), Официального интернет-портала правовой информации (http:// pravo.gov.ru), Портала открытых данных Российской Федерации (http://data.gov.ru) и др.; сайтов «РАБОТА.РУ» (https://www.rabota.ru/), OОО «Директум» (https://www.directum.ru), AO «Кодекс» (https://kodeksdoc.ru/about), «Работа в России» (https://trudvsem.ru), образовательной социальной сети «NSPortal» (https://nsportal.ru), ООО «Электронные офисные системы» (https://eos.ru), официальных сайтов президента России, Совета Федерации, Государственной думы, федеральных министерств, служб и агентств, регионов России и региональных органов власти и др.; программы автоматизации делопроизводства и электронного документооборота «Дело», «Директум», «1С: Документооборот», «Е1 Евфрат», «LanDocs» и др.

\section{Результаты и обсуждение}

\section{Понятие интерактивного документа}

Толкование термина «документ» закреплено в терминологическом стандарте 2013 г., где под документом понимается «зафиксированная на носителе информация с реквизитами, позволяющими ее идентифицировать» [ГОСТ Р 7.0.8-2013]. Если рассмотреть дефиниции данного термина, представленные в терминологических стандартах, действовавших ранее в нашей стране (ГОСТ 1970, 1983, 1998 гг.), можно увидеть, что в качестве основных признаков документа по-прежнему выделяют информацию и материальный носитель.

Информация - это содержание документа, все сведения, которые адресаты и исследователи могут получить, рассмотрев текст документа, его реквизиты и даже особенности материального носителя (например, по сорту бумаги, на которой составлен документ, можно сделать предположение о времени составления документа, если дата не указана в реквизитах).

Материальные носители бывают разными. В качестве основы для создания докумен- та применяется бумага, магнитная пленка, CD- и DVD-диски, карты памяти. Документ может существовать в компьютерной системе (локальной или глобальной), тогда материальная часть такого документа - это код, комбинация чисел, программа в компьютерной системе.

Базой для разработки и функционирования интерактивных документов является гипертекст.

Гипертекст - это «сложное лингвоинформационное образование, существование которого возможно преимущественно в киберсреде, обладающее навигационным аппаратом, оформленным посредством гиперссылок и “линков" (языковых и неязыковых), актуализирующих такие текстовые категории, как связность и цельность» [Попов, 2015, с. 171].

Термин «гипертекст» имеет множество толкований. «Гипертекстом называют Интернет, энциклопедию, справочник, книгу с содержанием и предметным указателем, а также любой текст, в котором обнаруживаются какие-либо ссылки (указания) на другие фрагменты» [Купер, 2000, с. 43].

Гипертекст - это связь информационных массивов, отдельные компоненты которых объединены не только тематически, но и ассоциативно [Желондиевская, 2011, с. 54].

Исследователи предлагают рассматривать термин «гипертекст» в узком и широком смысле. При узком толковании гипертекст это как минимум два текста, объединенные ссылкой. В широком смысле гипертекст - это текст, нарушающий, прекращающий или останавливающий линейное, последовательное повествование в целях внесения новой, дополнительной информации; первичный текст, разветвляющийся на вторичные тексты; текст с возможным по выбору пользователя переходом и внутренней междутекстовой связью; текст, по которому читатель проходит в нужном ему направлении; текст с множество внутренних ходов, не зависящих друг от друга; текст, который можно завершать или разворачивать по настроению пользователя [Тошович, 2015, с. 114-115].

Гипертекст рассматривается не только как текст, но и как метод, объединяющий документы; механизм, позволяющий организовать тексты или средство организации тек- 
стов; документация, которая ветвится [Купер, 2000, c. 49].

Технологии создания и использования гипертекста сделали возможным появление и функционирование интерактивных документов.

Под интерактивным документом мы понимаем электронный документ, форму представления гипертекста, специальную материальную конструкцию (код, программу, бытующие в электронной среде), созданную человеком для сохранения и передачи информации в пространстве и времени, приспособленную для прочтения текста (как логической или ассоциативной последовательности речевых или неречевых знаков).

\section{Виды интерактивных документов}

В зависимости от функциональных возможностей и численности пользователей мы выделяем следующие виды интерактивных документов: деловой портал, деловой сайт, программа автоматизации делопроизводства и электронного документооборота.

Деловые nорталь помогают осуществлять коммуникацию между государством и индивидом. Примером такого интерактивного документа можно назвать отечественный портал «Госуслуги». Он рассчитан на большое количество пользователей, включает актуальную информацию, связанную с различными аспектами социальной жизни. Сведения представлены в виде текстов, видеоматериалов, аудиозаписей. Тексты имеют разнообразную форму - таблица, анкета, корпус связных текстов. Через личные кабинеты пользователей осуществляется обратная связь в коммуникационном процессе. Есть ссылки на одноименные странички в социальных сетях. Многие органы исполнительной власти в России имеют порталы, подобные «Госуслугам».

В интернет-пространстве существует большое количество сайтов, используемых в процессе деловой коммуникации, например сайты, посвященные способам организации делопроизводства.

В делопроизводстве всегда фиксировались результаты устных деловых договоренностей. Сейчас под делопроизводством понимают деятельность, обеспечивающую документирование, документооборот, оперативное хранение и работу с документами [ГОСТ Р 7.0.8-2013]. Делопроизводство ведется в любой организации, независимо от ее вида, формы и правового статуса. Крупные организации создают, получают, обрабатывают, хранят документы в электронной форме, то есть применяют в своей работе системы автоматизации делопроизводства и электронного документооборота. Разработчики этих систем предлагают потребителям сайты, рассказывающие об электронном документообороте, его преимуществах и способах приобретения программ электронного документооборота.

Стремление упростить и ускорить все деловые процессы, облегчить функционирование фирм, получить в наиболее короткие сроки максимальную прибыль способствовало унификации разных аспектов ведения бизнеса (бухгалтерия, правовое обеспечение, делопроизводство и т. д.). Их закрепление в виде алгоритмов привело к созданию большого количества компьютерных программ разной сложности, которые могут работать как автономно на отдельном ПК или в локальной сети, так и используя ресурсы глобальной сети Интернет.

\section{Структура интерактивного документа}

Материальная и информационная части документа имеют определенную структуру. Например, структурой официального документа является его формуляр - совокупность реквизитов, характерных для того или иного вида документов, расположенных в определенной последовательности. При этом под официальным документом понимается «документ, созданный организацией, должностным лицом или гражданином, оформленный в установленном порядке» [ГОСТ Р 7.0.8-2013].

Структурность - это одно из основных свойств любого документа. Структура позволяет документу существовать, выполнять свои функции в качестве самостоятельного, отдельного объекта действительности. Как и другие атрибуты документа, структура его информационной составляющей подвержена изменениям. В настоящее время можно выделить два направления, в которых они происходят: первое - формализация структуры, унификация ее компонентов; второе - создание документов без четкой структуры. 
Изменения в направлении дальнейшей формализации, как показано исследователями, обнаруживают документы долгосрочного планирования (стратегия развития [Быстрова, 2017], концепция модернизации образования [Косова, Белоконева, 2011]; медицинские документы (медицинская карта стационарного больного) [Ромашова, 2014]), научные документы (автореферат диссертации) [Краснова, 2009] и др.). Форму большинства таких документов можно назвать жесткой: она установлена нормативно-правовыми актами федерального уровня. Отклонение от установленной формы при составлении или заполнении такого документа может привести к негативным правовым последствиям. Языковые средства, используемые для создания такого документа, также подвергаются тщательному отбору: они должны соответствовать требованиям официально-делового стиля.

Изменения, приводящие к созданию документов без четкой структуры, прослеживаются в документах PR-деятельности (корпоративное издание, политика в области качества [Плигина, 2014]) и некоторых других видах документов.

По структуре интерактивные документы отличаются от других объектов действительности, созданных для хранения и передачи информации во времени и пространстве. Интерактивные документы включают текстовую и мультимедийную информацию, а также ссылки, позволяющие переходить от одного информационного компонента к другому.

Документный текст интерактивных документов включает вербальный компонент (собственно текстовую часть) и невербальные компоненты, характеризующиеся большим видовым разнообразием.

Вербальный компонент интерактивного документа. Официальный характер документированной информации определяет требования к языковому наполнению документов (вербальному компоненту документного текста). Традиционный документный текст отличается точностью, ясностью, логичностью и краткостью, нейтральным тоном изложения информации. Реализации этих требований способствует употребление специальных языковых и речевых средств, выработанная практикой делопроизводства пос- ледовательность представления данных. Созданный с соблюдением таких правил документ позволяет экономить время на его прочтение и обработку, повышает однозначное восприятие документного текста участниками деловой коммуникации.

Развитие информационных технологий, создание и активное использование гипертекста, появление интерактивных документов изменили отношение к языковому наполнению документного текста.

Некоторые исследователи считают, что в русском языке для виртуальной коммуникации формируется новый стиль - стиль интернет-общения [Виноградова, 2004; Довгаль, Михайлова, 2014]. Он характеризуется «письменным произношением, гиперинтертекстуальностью и запечатленной разговорностью. При этом качественно новым признаком стиля является его спонтанность, несмотря на воспроизводимость» [Виноградова, 2004]. Специфика данного стиля состоит в активном использовании коммуникантами компьютерных терминов, компьютерного сленга (жаргона), интернет-сленга, молодежного сленга.

Необходимо отметить, что эти особенности не прослеживаются в деловой электронной коммуникации, где статус официального общения по-прежнему определяет отбор языковых единиц. Влиянию спонтанной устной разговорной речи больше подвергается взаимодействие посредством чатов, блогов, форумов, социальных сетей, гостевых книг, телеконференций.

Неотъемлемой чертой официальноделового стиля является активное использование терминологических единиц. Рассмотрим терминологию интерактивных документов на примере портала «Госуслуги» (https://www.gosuslugi.ru/).

Термины, функционирующие в интерактивных документах, распределены нами по тематическим группам.

1. Документы:

- виды (архивный документ, архивная справка, виза, доверенность, закон, заявление, заказное письмо, миграционная карта, направление, паспорт гражданина РФ, дипломатический паспорт, служебный (официальный) паспорт, платежный доку- 
E.С. Белоус. Интерактивные документы: языковые особенности и документный статус

мент, приказ, проездной документ, расписка, уведомление, свидетельство о рождении, свидетельство об усыновлении, сертификат, справка, справка об отсутствии судимости, справка о реабилитачии жертв политических репрессий, сертификат на материнский капитал, федеральный закон, федеральный конституционный закон, ОСАГО, СНИЛС, ПТС, СТС);

- информационная составляющая (фирменный бланк организации, контактные данные, выписка, заверенный перевод, адресно-справочная информачия);

- материальный носитель (бумажная форма, электронная форма, первый экземпляр, дубликат, электронный сертификат, копия);

- операции с документами (аннулирование, восстановление, выдача, заверение, заказ, замена, заполнение, ламинирование, отправка, подача, получение, предоставление, проверка, рассмотрение, регистрачия, формирование, хранение).

2. Органы власти: МВД России, ПФР, ГУВМ МВД России, ФНС России, ФССП России, Минздрав России, МЧС России, Росреестр, Роскомнадзор, ФСС РФ, ФДА, Роспотребнадзор, Минюст, Фонд сочиального страхования РФ, ФСБ, ГИМС МЧС России, Госавтоинспекиия.

3. Учреждения: дошкольное учреждение, загс, архив, суд, индивидуальный предприниматель, крестьянское (фермерское) хозяйство, общество с ограниченной ответственностью, МФЦ.

4. Портал:

- разделы (услуги, жизненные ситуации, оплата, поддержка, поиск, личный кабинет);

- подразделы (популярное на портале, частые вопросы, интересно и полезно);

- структурные компоненты (категория, форма, сервис, электронные услуги, неэлектронные услуги, платформа, модуль, виджет, государственная услуга).

5. Юридические термины (в определенной категории портала употребляются термины той отрасли права, которая регламентирует данную категорию):

- семейного права (регистрация бра$\kappa a$, регистрация рождения, материнский капитал, регистрация усыновления (удочерения), установление отцовства);

- трудового права (работодатель, отпуск по беременности и родам);

- права социального обеспечения (пособие, единовременные и ежемесячные пособия на детей, ежемесячное пособие по уходу за ребенком, пособие по беременности и родам, страхователь, застрахованное лицо);

- налогового права (налоговая задолженность, налоговый учет, налоговая декларация, имущественный налоговый вычет, налог на профессиональный доход, НДФЛ);

- пенсионного права (накопительная пенсия, страховая пенсия, пенсионер);

- международного права (апостиль, вид на жительство, приглашение на въезд в Российскую Федераиию, разрешение на временное проживание, трудовой патент, право на работу);

- гражданского права (физическое лиио, юридическое лиио, иностранный гражданин, лищо без гражданства, регистрачия по месту жительства, регистращия по месту пребывания);

- транспортного права (право на управление транспортным средством, регистрация транспортного средства, регистраиионная история автомобиля, дорожный штраф);

- банковского права (ипотека, рефинансирование кредита) и др.

Как видим, термины, функционирующие на портале, относятся к правовой или делопроизводственной сферам, что подчеркивает официальный характер общения посредством интерактивных документов.

При анализе вербального компонента интерактивных документов были выявлены и другие языковые особенности: использование эмоционально окрашенной лексики в качестве синонимов общеупотребительных слов и иногда терминов (ребенок - новорожденный мальщ), нарушение структуры синтаксических конструкций, характерных для официального стиля (Но сначала в любом случае стоит пойти в загс, а там уже подскажут), употребление конструкций, свойственных для разговорного стиля (Что делать, если утеряны все документыт?; Чтобы получить дуб- 
ликат свидетельства, нужно обратиться в загс, где хранится; Ламинирование - это тоже порча бланка, поэтому когда придется ставить на свидетельстве какие-то отметки, придется его менять) и др. Данные особенности указывают на то, что разработчики хотели сделать содержание портала более доступным пользователям, избежав сложных оборотов и конструкций, употребляя разговорную лексику. Однако такое изложение информации не всегда способствует точной и однозначной передаче смысла сообщения.

Невербальный компонент интерактивного документа формируется следующими элементами:

1. Системные знаки (знаки, часто использующиеся в навигации по интерактивному документу):

- иконки стрелок для перехода вверх и вниз, вперед и назад;

- интерактивные кнопки, при нажатии на них моделируется процесс реального нажатия на кнопку в физическом пространстве (звук, изменение объема кнопки и т. п.).

2. Символы:

- операций, которые можно осуществлять в системе: переход на домашнюю страницу (в виде домика), отправка и прием сообщений (конверт), пометить как избранное (звездочка), открыть видеофайл или звуковой файл (направленный треугольник) и т. п.;

- содержания (иконка документа выглядит как лист бумаги с записями, иконка папки с документами - как приоткрытая папка и т. д.).

3. Интерактивные компоненты: мультимедийные вставки, анимация.

4. Звуки.

5. Фильмы.

6. Изображения: рисунки, фотографии.

7. Элементы образного визуального кода: шрифт, цвета, формы, выделения, рамки, линии, параграфемные средства (представление текста, при котором буквы в словах (сочетания букв или целые слова) могут заменяться рисунками, а фразы получают дополнительные смысловые оттенки). Исследователи в зависимости от механизма создания выделяют три группы параграфемных средств: топографемные средства (плоскостное варьирование текста); супраграфемные средства (шрифтовое варьирование - разрядка, выбор определенной гарнитуры и т. д.); синграфемные средства (художественно-стилистическое варьирование знаков пунктуации) [Баранов, Паршин, 1989]. Можно предположить, что в интерактивных документах используются параграфемные средства всех типов, однако это предположение требует дополнительной проверки на более широком эмпирическом материале.

8. Структурные элементы:

- информационные единицы или узлы, размер которых может быть представлен разным объемом (от предложения до книги);

- гиперссылки (линки), обеспечивающие переход от одного узла к другому;

- закладки (указатели), закрепляющие гипертекстовую ссылку.

Невербальные компоненты помогают оптимизировать взаимодействие автора документа с его получателем.

Рассмотрим невербальные составляющие текста интерактивного документа на примере портала «Госуслуги». В данном документе используются следующие виды невербальных компонентов.

1. Системные знаки. Представлены в цветном варианте. В соответствии с принципами организации портала интерактивные кнопки делятся на две группы (см. рис. 1): услуги и жизненные ситуации. В первом случае кнопки решены в виде пиктограмм (например, кнопки «Выдача или замена паспорта гражданина РФ», «Получение права на управление ТС» и др.), во втором - в виде рисунков («Получение образования», «Приобретение жилой недвижимости» и др.). При нажатии на кнопку пользователь попадает в соответствующий раздел.

Изображения на интерактивных кнопках выбраны не случайно. Они имеют семантическую и ассоциативную схожесть с реальными объектами, что создает эффект пространственного присутствия, пользователи чувствуют себя комфортнее при работе с таким документом.

2. Символы. Представлены в цветном варианте. Делятся на две группы: символы операций, которые можно осуществлять в системе, и символы содержания (см. рис. 2). Служат для навигации по порталу. Позволяют отыскать нужную операцию, не обращаясь к тексту. 
E.С. Белоус. Интерактивные документы: языковые особенности и документный статус

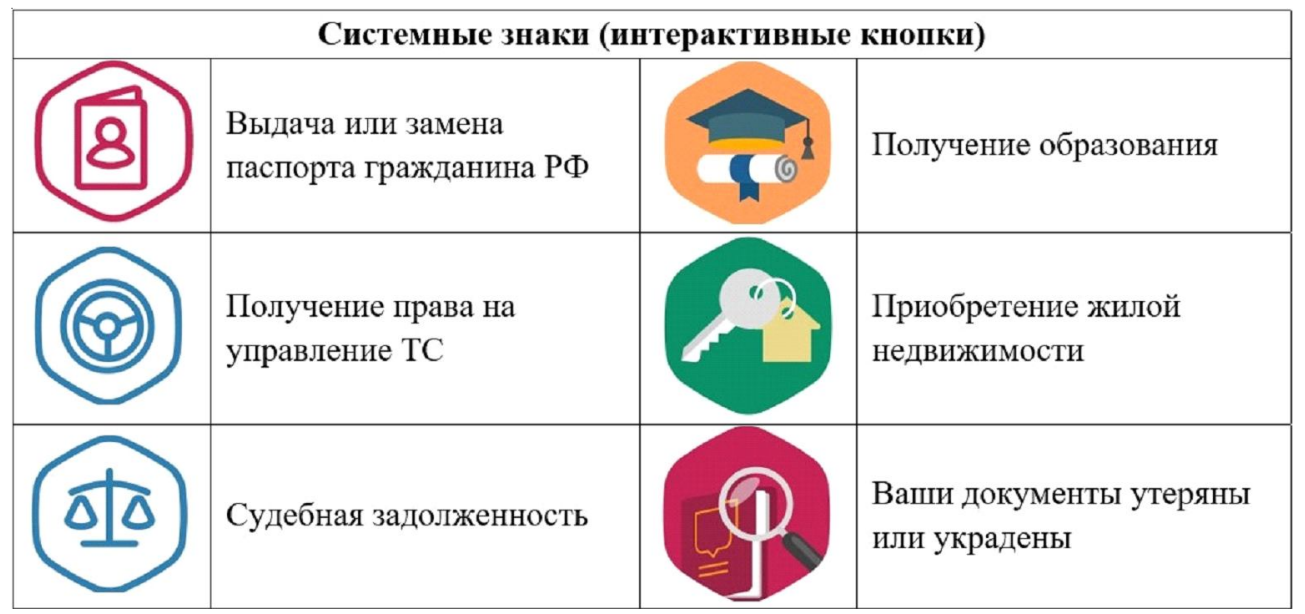

Рис. 1. Системные знаки в интерактивных документах

Fig. 1. System signs in interactive documents

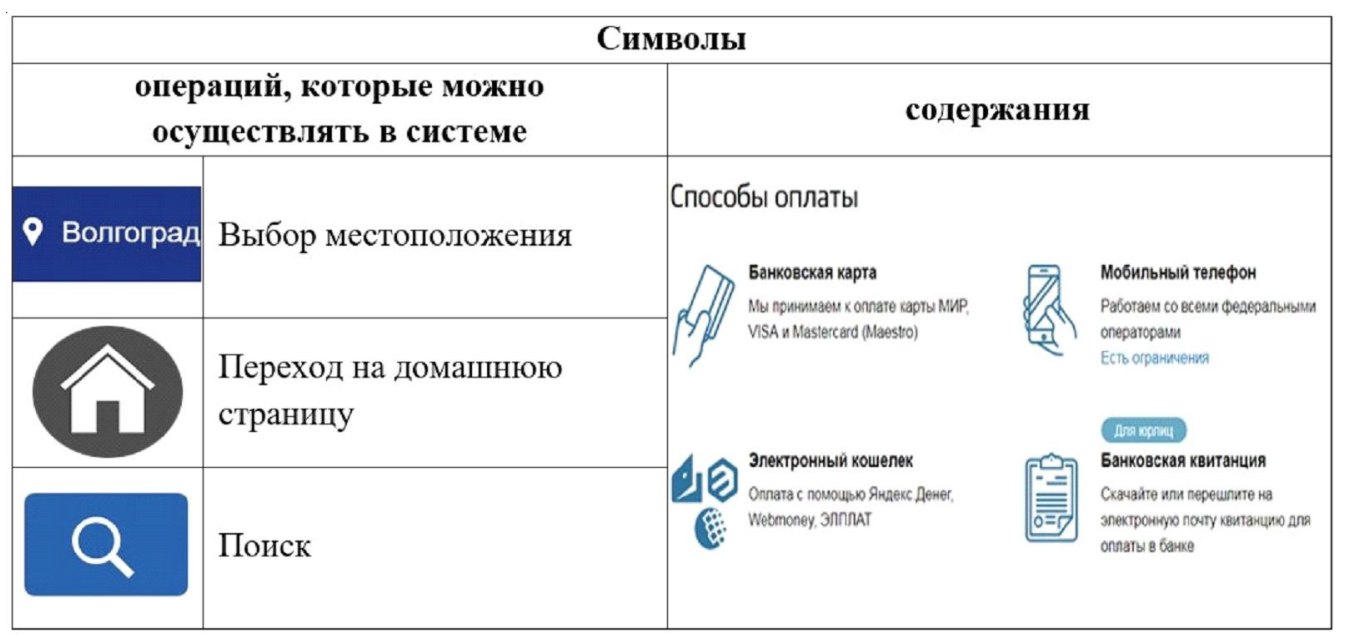

Рис. 2. Символы в интерактивных документах

Fig. 2. Symbols in interactive documents

3. Изображения. Включают герб РФ, эмблему портала, эмблемы органов власти и иллюстрации (см. рис. 3). Даны как в чернобелом, так и цветном варианте. Например, герб РФ изображен черно-белым, эмблемы органов власти и иллюстрации - цветными.

Иллюстрации - вид изображений, используемый для разъяснения последовательности операций или заполнения документов; наглядного представления компьютерных программ; оформления разделов. В первых двух случаях они выполняют информационную функцию, в последнем - гедоническую (создают нужный эмоциональный настрой).

\section{4. Элементы образного визуального} кода. Для оформления портала применяется много видов шрифтов разного размера. Цветовой код заложен в элементах графики, относящихся к услуге: значках, символах, кнопках. Для каждой категории установлен уникальный цвет, например: семья и дети - голубой; транспорт и вождение - синий; паспорта, регистрации, визы - розовый; налоги и финансы - фиолетовый и т. д. Преобладающие цвета фона - синий, серый, белый и черный. Эмблема портала выполнена в цветах российского флага (на белом фоне синими и красными буквами написано госуслуги, надпись заключена в шестиугольник со скругленными углами, при этом слово госуслуги разбито на две части (гос и услуги), которые размещаются на двух строчках). 


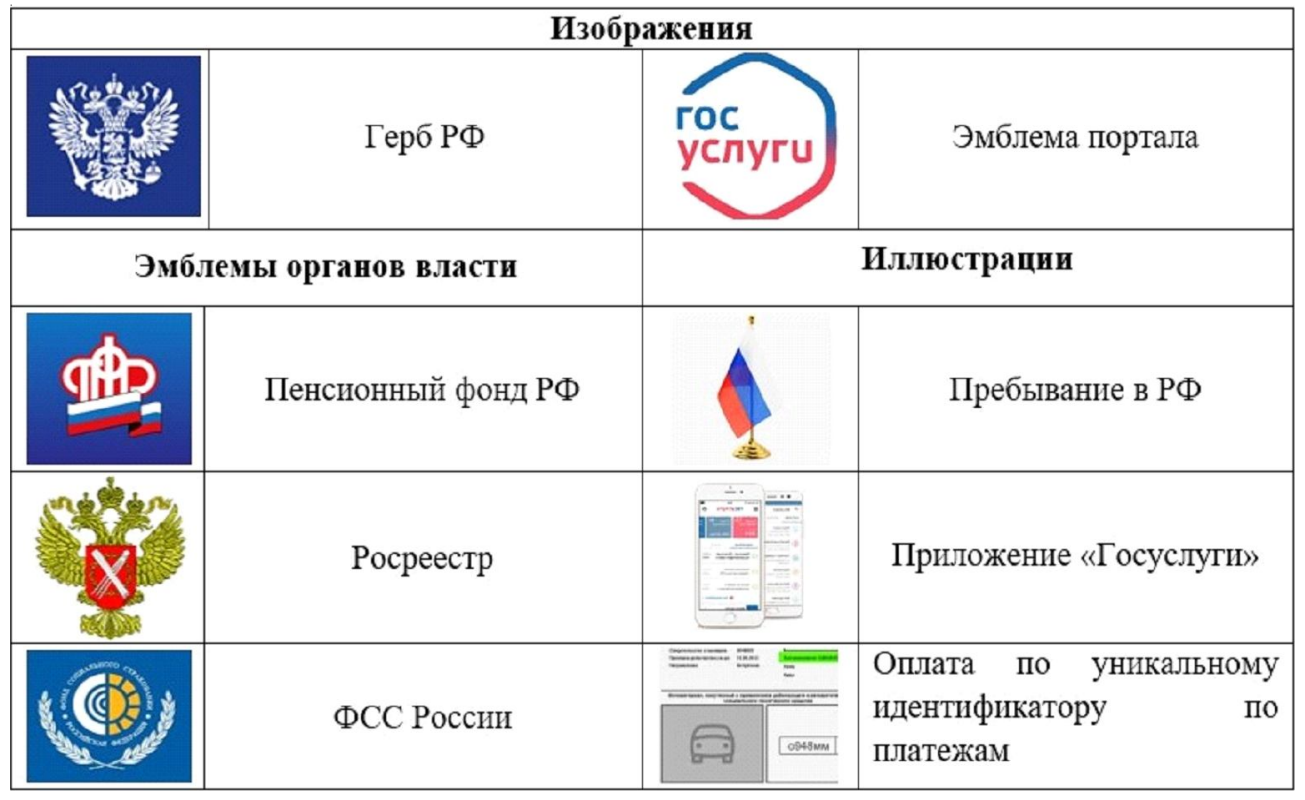

Рис. 3. Изображения в интерактивных документах

Fig. 3. Images in interactive documents

Вместе элементы образного визуального кода создают запоминающийся дизайн. Органы власти в соответствии с определенными рекомендациями разрабатывают свои сайты, используя данный или схожий дизайн. По тому же принципу оформлен интерфейс информационных порталов, правовых платформ и т. д. Их дизайн выступает не только средством представления гипертекста, но и уникальным инструментом передачи сведений.

При этом воздействие на получателя сообщения происходит как на рациональном, так и на эмоциональном уровне. Комфортная цветовая палитра, удобный макет, знакомая навигация создают позитивный образ автора документа. Возрастает роль изображения как средства передачи информации.

5. Структурные элементы. На портале представлены все необходимые для гипертекста структурные элементы - закладки, гиперссылки и информационные узлы. Используются ссылки разных типов: ссылки, обеспечивающие переход на другие страницы, и ссылки, запускающие выполнение каких-либо дополнительных функций (открытие диалогового окна, показ раздела и др.). К некоторым ссылкам могут быть добавлены значки, сообщающие о дополнительных возможностях. Цвет значка определяется дизайн-макетом.
Дополнительные значки имеют привычные для пользователя вид и семантику (см. рис. 4).

Разработанный по итогам проведения масштабных исследований единый государственный стиль электронных услуг обеспечивает качество и комфортность работы для всех граждан.

Невербальные компоненты традиционных документов - реквизиты, включающие графическую информацию или линии, отделяющие один реквизит от другого. Они представлены печатями, штампами, угловыми отметками. Редко применяются два-три вида шрифта, курсив или разрядка.

По сравнению с документами на традиционных носителях, интерактивные документы содержат больше невербальных компонентов, они разнообразнее по виду и выполняют больше функций: кроме структурирования документа они несут дополнительную информацию, определенным образом организуют документный текст, создают эффект «присутствия» и положительный эмоциональный настрой пользователя при работе с документом.

\section{Заключение}

Интерактивные документы являются продуктом современной деловой коммуникации. Все большее количество людей исполь- 
E.С. Белоус. Интерактивные документы: языковые особенности и документный статус

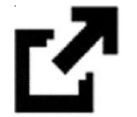

A

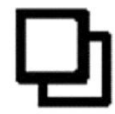

Б

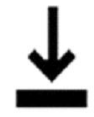

B

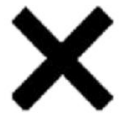

Г

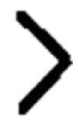

Д

Рис. 4. Значки в интерактивных документах:

$A$ - «ссылка ведет на внешний ресурс»; Б - «ссылка откроется в новом окне»; $B$ - «ссылка на файл, который будет скачан»; $\Gamma$ - «действие удалить»; Д - «переход»

Fig. 4. Icons in interactive documents:

$A$ - external link; $B$ - link opens in a new window;

$V$ - link to a downloadable file; $G$ - action "to delete"; $D$ - shift

зует их для решения своих проблем в сфере ведения бизнеса, образования, здравоохранения, взаимодействия с органами власти, реализации экономических прав.

Интерактивные документы создаются с той же целью, что и традиционные документы на бумажных носителях, а именно для хранения и передачи информации во времени и пространстве. Они разрабатываются по принципу организации гипертекста - совокупности информационных массивов, баз данных, программ поиска и хранения информации, программ представления информации пользователю, специализированных компонентов интерфейса, позволяющих осуществлять навигацию по разнообразному контенту. Интерактивный документ можно рассматривать в качестве формы представления гипертекста.

Важными признаками интерактивных документов являются характер материального носителя и характер информации. Поскольку интерактивные документы - это разновидность электронных документов, их материальный носитель представляет собой код, программу, бытующие в электронной среде. Информационная часть (или документный текст) интерактивных документов включает вербальный и невербальный компоненты.

Анализ вербального компонента документного текста интерактивных документов показал наличие большого количества терминологических единиц. Употребление терминов определяет точность и однозначность документного послания. Поэтому можно сказать, что интерактивные документы, так же как и документы на традиционных бумажных носителях, разрабатываются с учетом требований официально-делового стиля. Однако употребление эмоционально окрашенных слов и конструкций, свойственных разговорной речи, свидетельствует о тенденции перехода от официального к менее официальному общению в электронной среде, независимо от деловой ситуации.

Невербальные компоненты, применяемые в традиционных документах, немногочисленны по видам (печати, штампы, эмблемы, ограничительные отметки для реквизитов). Они выполняют следующие функции: структурируют текст, несут дополнительную информационную нагрузку, способствуют эстетическому восприятию документа. Некоторые компоненты придают документам юридическую силу. Невербальные компоненты документного текста интерактивных документов отличаются большим видовым разнообразием и сложностью реализуемых функций. Кроме структурирования документа они позволяют отыскать нужный раздел документа без обращения к тексту. Это связано с потребностью адресата в визуализации информации, детерминированной клиповостью мышления современного человека. Включение в документы мультимедийных, аудио- и видеофрагментов позволяет получить наглядное представление об интересующем объекте, сконцентрировать больше данных по определенной теме. Кроме того, использование невербальных компонентов помогает создать «дружелюбный интерфейс», сблизить адресата и адресанта документного послания.

Интерактивные документы характеризуются определенной структурой, но она менее формализована по сравнению с традиционными официальными документами, оформление которых регламентируется правовыми актами и образцами, закрепленными в унифицированных системах документации.

Развитие общества неизменно влечет изменение форм и способов коммуникации. 
Информационные технологии оперативно реагируют на эти изменения, предлагая новые инструменты для делового общения. Изучение данных инструментов является перспективным направлением исследований в рамках документной лингвистики.

\section{СПИСОК ЛИТЕРАТУРЫ}

Баранов А. Г., Паршин Л. Б., 1989. Воздействующий потенциал варьирования в сфере метаграфемики // Проблемы эффективности речевой коммуникации : сб. науч.-аналит. обзоров. М. : ИНИОН. С. 41-115.

Белоус Е. С., 2010. Понятийно-терминологический состав предметной области «управление документацией» // Вестник Челябинского государственного университета. № 32 (213). С. 24-28.

Быстрова А. С., 2017. Жанровые параметры стратегии как документа долгосрочного планирования // Вестник Волгоградского государственного университета. Серия 2, Языкознание. Т. 16, № 3. С. 199-206. DOI: https://doi.org/ 10.15688/jvolsu2.2017.3.20.

Виноградова Т. Ю., 2004. Специфика общения в Интернете // Русская и сопоставительная филология: лингвокультурологический аспект. Казань : Изд-во Казан. федер. ун-та. С. 63-67.

ГОСТ Р 7.0.8-2013. Делопроизводство и архивное дело. Термины и определения, 2014. Введ. 2014-03-01. М. : Стандартинформ. 26 с.

ГОСТ Р 7.0.97-2016. Организационно-распорядительная документация. Требования к оформлению документов, 2018. Введ. 2018-07-01. М. : Стандартинформ. 35 с.

Довгаль Л. П., Михайлова С. Е., 2014. Лингвистические особенности виртуальной коммуникации // Иностранные языки: лингвистические и методические аспекты. № 29. С. 213-219.

Желондиевская Л. В., 2011. Гипертекст графического дизайна // Вестник Оренбургского государственного университета. № 9 (128). С 54-57.

Косова М. В., Белоконева К. А., 2011. Специфика субъекта и адресата документного текста // Вестник Нижегородского университета им. Н.И. Лобачевского. № 6-2. С. 319-323.

Краснова О.Н., 2009. Динамика реквизитного состава научного документа как реализация сигнальной функции // Известия высших учебных заведений. Проблемы полиграфии и издательского дела. Научно-практический журнал. № 1 (янв. - февр.). С. 77-81.

Купер И. Р., 2000. Гипертекст как способ коммуникации // Социологический журнал. № 1/2. C. $36-57$.
Кушнерук С. П., 2007. Лингвистика документной коммуникации (теоретические аспекты). Волгоград : Волгогр. науч. изд-во. 276 с.

Кушнерук С. П., Тюрикова Н. А., 2015. Динамика терминологии и ее отражение в терминологических стандартах (предметная область «Делопроизводство и архивное дело») // Вестник Волгоградского государственного университета. Серия 2, Языкознание. № 1 (25). C. 158-164. DOI: http://dx.doi.org/10.15688/jvolsu2.2015.1.19.

Литвинов А. В., Матюшенко В. В., 2013. Периферийные зоны деловой коммуникации // Филологические науки. Вопросы теории и практики. № 11-1 (29). С. 106-109.

Плигина Е. С., 2014. Документный текст как инструмент PR-коммуникации (на примере годового отчета) // Мир науки, культуры, образования. № 1 (44). С. 192-195.

Попов Е. А., 2015. Подходы к изучению гипертекста // Вестник Ленинградского государственного университета им. А.С. Пушкина. СПб. : Изд-во Ленингр. гос. ун-та им. А С. Пушкина. Т. 7, № 1. C. 167-171.

Ромашова О. В., 2014. Жанрово-стилевая специфика медицинского документа (на материале медицинской карты стационарного больного) // Мир науки, культуры, образования. № 5 (48). C. $127-130$.

Тошович Б., 2015. Стилистически релевантные свойства и разновидности гипертекста // Экология языка и коммуникативная практика. № 1. С. 114-125.

\section{REFERENCES}

Baranov A.G., Parshin L.B., 1989. Vozdeystvuyushchiy potentsial varirovaniya $v$ sfere metagrafemiki [The Potential Impact of Variation in the Field of Metaproperty]. Problemy effektivnosti rechevoy kommunikatsii: sb. nauch.-analit. obzorov [Problems of Efficiency of Speech Communication: Collection of Scientific and Analytical Reviews]. Moscow, INION, pp. 41-115.

Belous E.S., 2010 Ponjatijno-terminologicheskij sostav predmetnoj oblasti «upravlenie dokumentaciej» [Notional and Terminological Composition of Knowledge Domain 'Records Management']. Vestnik Chelyabinskogo gosudarstvennogo universiteta [Bulletin of Chelyabinsk State University], no. 32 (213), pp. 24-28.

Bystrova A.S., 2017. Zhanrovye parametry strategii kak dokumenta dolgosrochnogo planirovaniya [Genre Parameters of Strategy as a Document of Long-Term Planning]. Vestnik Volgogradskogo gosudarstvennogo universiteta. Seriya 2. 
Yazykoznanie [Science Journal of Volgograd State University. Linguistics], vol. 16, no. 3, pp. 199-206. DOI: https://doi.org/10.15688/ jvolsu2.2017.3.20.

Vinogradova T.U., 2004. Spetsifika obshcheniya v Internete [Specifics of Communication on the Internet]. Russkaya $i$ sopostavitelnaya filologiya: lingvokulturologicheskiy aspect [Russian and Comparative Philology: Linguistic and Cultural Aspect]. Kazan, Izd-vo Kazanskogo federalnogo universiteta, pp. 63-67.

GOST R 7.0.8-2013. Deloproizvodstvo i arkhivnoe delo. Terminy i opredeleniya [National Standard of the Russian Federation GOST R 7.0.8-2013. Records Management and Organization of Archives. Terms and Definitions)], 2014. Introduced March 1, 2014. Moscow, Standartinform Publ. $26 \mathrm{p}$.

GOST $R$ 7.0.97-2016. Organizatsionnorasporyaditelnaya dokumentatsiya. Trebovaniya $k$ oformleniyu dokumentov [National Standard of the Russian Federation GOST R 7.0.97-2016. Organizational and Administrative Documentation. Requirements for the Paperwork], 2018. Introduced July 1, 2018. Moscow, Standartinform Publ. 35 p.

Dovgal L.P., Mikhailova S.E., 2014. Lingvisticheskie osobennosti virtualnoy kommunikatsii [Linguistic Features of Virtual Communication]. Inostrannye yazyki: lingvisticheskie $i$ metodicheskie aspekty [Foreign Languages: Linguistic and Methodological Aspects], no. 29, pp. 213-219.

Zhelondievskaya L.V., 2011. Gipertekst graficheskogo dizayna [Hypertext of Graphic Design]. Vestnik Orenburgskogo gosudarstvennogo universiteta [Vestnik of the Orenburg State University], no. 9 (128), pp. 54-57.

Kosova M.V., Belokoneva K.A., 2011. Spetsifika subyekta i adresata dokumentnogo teksta [Contribution to the Problem of Speech Organization of a Documental Text]. Vestnik Nizhegorodskogo universiteta im. N.I. Lobachevskogo [Vestnik of Lobachevsky University of Nizhni Novgorod], no. 6-2, pp. 319-323.

Krasnova O.N., 2009. Dinamika rekvizitnogo sostava nauchnogo dokumenta kak realizaciya signalnoy funktsii [Dynamics of the Requisite Composition of a Scientific Document as the Implementation of the Signal Function]. Izvestiya vysshikh uchebnykh zavedeniy. Problemy poligrafii $i$ izdatelskogo dela. Nauchno-prakticheskiy zhurnal [Proceedings of the Institutions of Higher Education. Issues of the Graphic Arts and Publishing. Scientific and Practical Journal], no. 1 (January-February), pp. 77-81.
Kuper I.R., 2000. Gipertekst kak sposob kommunikatsii [Hypertext as a Way of Communication]. Sotsiologicheskiy zhurnal [Sociological Journal], no. 1/2, pp. 36-57.

Kushneruk S.P., 2007. Lingvistika dokumentnoy kommunikatsii (teoreticheskie aspekty) [Linguistics of Document Communication (Theoretical Aspects)]. Volgograd, Volgogradskoe nauchnoe izd-vo. $276 \mathrm{p}$.

Kushneruk S.P., Tyurikova N.A., 2015. Dinamika terminologii i ee otrazhenie $\mathrm{v}$ terminologicheskikh standartakh (predmetnaya oblast «deloproizvodstvo i arkhivnoe delo») [The Dynamics of Terminologyand Its Representation in Terminological Standards (Records Management and Archiving Subject Field)]. Vestnik Volgogradskogo gosudarstvennogo universiteta. Seriya 2. Yazykoznanie [Science Journal of Volgograd State University. Linguistics], no. 1 (25), pp. 158-164. DOI: http://dx.doi.org/ 10.15688/jvolsu2.2015.1.19.

Litvinov A.V., Matyushenko V.V., 2013. Periferiynye zony delovoy kommunikatsii [Peripheral Zones of Business Communication]. Filologicheskie nauki. Voprosy teorii i praktiki [Philological Science. Theory and Practice], no. 11-1 (29), pp. 106-109.

Pligina E.S., 2014. Dokumentnyy tekst kak instrument PR-kommunikatsii (na primere godovogo otcheta) [Document Text in Public Relations (Illustrated by Annual Report)]. Mir nauki, kultury, obrazovaniya [The World of Science, Culture and Education], no. 1 (44), pp. 192-195.

Popov E.A., 2015. Podkhody k izucheniyu giperteksta [Approaches to the Study of Hypertext]. Vestnik Leningradskogo gosudarstvennogo universiteta im. A.S. Pushkina [Science Journal of Leningrad State University Named After A.S. Pushkin], vol. 7, no. 1, pp. 167-171.

Romashova O.V., 2014. Zhanrovo-stilevaya spetsifika meditsinskogo dokumenta (na materiale medicinskoy karty statsionarnogo bolnogo) [Genre-Stylistic Specifics of a Medical Document (On the Material of a Patient's Medical Report)]. Mir nauki, kultury, obrazovaniya [The World of Science, Culture and Education], no. 5 (48), pp. 127-130.

Toshovich B., 2015. Stilisticheski relevantnye svoystva i raznovidnosti giperteksta [Stylistically Relevant Characteristics and Variety of Hypertext]. Ekologiya yazyka $i$ kommunikativnaya praktika [Ecology of Language and Communicative Practice], no. 1, pp. 114-125. 


\section{Information About the Author}

Elena S. Belous, Candidate of Sciences (Philology), Associate Professor, Department of Russian Language, Volgograd State Technical University, Prosp. im. Lenina, 28, 400005 Volgograd, Russia, cars@vstu.ru, https://orcid.org/0000-0001-6703-0739

\section{Информация об авторе}

Елена Сергеевна Белоус, кандидат филологических наук, доцент кафедры русского языка, Волгоградский государственный технический университет, просп. им. Ленина, 28, 400005 г. Волгоград, Россия, cars@vstu.ru, https://orcid.org/0000-0001-6703-0739 